February 2009 ( $3^{\text {rd }}$ revision $)$

\title{
Eddy-driven pulses of respiration in the Sargasso Sea
}

\author{
Beatriz Mouriño-Carballido ${ }^{1}$ \\ Applied Physics and Ocean Engineering Department. Woods Hole Oceanographic Institution, \\ Woods Hole, MA 02543-1541, USA. \\ ${ }^{1}$ Now at Departamento de Ecoloxía e Bioloxía Animal, Universidade de Vigo, Vigo, \\ Pontevedra, 36200, Spain.
}

Corresponding author. Tel +34 986 812591; Fax +34 986 812551; E-mail: bmourino@uvigo.es 


\section{Abstract}

2 An analysis of nine years of data from the NW subtropical Atlantic reveals that

3 variability in heterotrophic processes associated with (sub)mesoscale features has a

4 major impact on the balance between photosynthesis and respiration. Higher indirect

5 estimates of net community production (NCPe) are associated with the center of Mode

6 Water Eddies (MWE) and frontal regions between cyclonic and anticyclonic eddies

7 (CA). The increase in NCPe observed at the center of MWE is driven mainly by an

8 increase in autotrophic production, whereas in CA enhanced NCPe rates are the result of

9 an important reduction in bacterial respiration. Both features also exhibit a decrease in

10 nitrate concentration, consistent with nutrient consumption, and relative increases in

11 oxygen anomaly and particulate and dissolved organic carbon in the upper $200 \mathrm{~m}$.

12 Plankton community composition in CA and MWE is characterized by the reduction in

13 bacterial biomass, and the dominance of Prochlorococcus and Synechococcus in CA,

14 and diatoms and dinoflagellates in MWE. Contrary to a common assumption, these

15 results show for the first time that in ecosystems influenced by (sub)mesoscale

16 dynamics, respiration can be as variable as photosynthesis.

18 Keywords: (sub)mesoscale, photosynthesis, respiration, net community production, 19 Sargasso Sea 


\section{Introduction}

2 Net community production, the balance between gross primary production and

3 total respiration, defines the metabolic state of the euphotic zone and sets a constraint on

4 the amount of organic carbon sinking to the deep ocean (del Giorgio and Duarte, 2002).

5 The relative constancy of organic matter decomposition (respiration) with respect to

6 variable production due to photosynthesis has been a major assumption in contemporary

7 oceanography (Karl et al., 2003). One of the reasons ocean respiration is considered less

8 variable than photosynthesis is that planktonic microbes, particularly heterotrophic

9 bacteria, utilize a diverse array of organic matter, and not just that derived from local

10 primary production (Karl et al., 1998).

11 Over the last several years an intense research effort has been focused on 12 investigating the enigmatic observation that respiration can exceed photosynthesis in 13 large areas of the subtropical ocean (Duarte et al., 1999; Williams, 1998), where 14 geochemical estimates indicate that these regions are in balance or behave as net sinks 15 for $\mathrm{CO}_{2}$ (Hansell et al., 2004; Najjar and Keeling, 2000; Riser and Johnson, 2008). One 16 of the hypotheses proposed to explain this discrepancy postulates the existence of short 17 intensive bursts of photosynthesis, which charge the organic reservoir, and which 18 respiration slowly and steadily discharges (Karl et al., 2003). Mesoscale phenomena are 19 a mechanism that could generate high-frequency increases of photosynthesis to support 20 this hypothesis (Gonzalez et al., 2001; Maixandeau et al., 2005).

21 The ocean's subtropical gyres have been considered as relatively constant and 22 low productivity ecosystems (Eppley et al., 1973). However, recent studies in these 23 regions report important temporal and spatial variability in photosynthesis (Maranon et 24 al., 2000). A number of methodological issues associated with respiration measurements 25 in systems with low productivity (Williams and Jenkinson, 1982), has severely 
1 hampered the development of a global database. In fact, the global dataset of

2 respiration, when compared to that of ${ }^{14} \mathrm{C}$-based primary production, is about $1 \%$

3 (Williams and Del Giorgio, 2005). As a result, respiration remains the least constrained

4 term in most models of ocean-atmosphere gas exchange (Balkanski et al., 1999). The Bermuda Atlantic Time-series Study (BATS) site is located in the

6 subtropical gyre of the Atlantic Ocean, in the northwest corner of the Sargasso Sea.

7 BATS is designed to measure seasonal and interannual variability in biogeochemical 8 parameters (Steinberg et al., 2001), and measurements taken since 1988 are available at 9 http://bats.bios.edu/. The station is in an area of weak Gulf Stream recirculation with a net flow towards the southwest and intense hydrographic mesoscale activity throughout

11 the region (Cianca et al., 2007). Three different types of mesoscale eddies have been 12 identified in the Sargasso Sea (McGillicuddy et al., 1999): cyclones, anticyclones, and 13 mode-water eddies (MWE). Cyclones and MWE tend to displace upper-ocean 14 isopycnals toward the surface, causing nutrient input into the euphotic zone and the 15 stimulation of photosynthesis. There is growing evidence that primary production occurring both at the scale of mesoscale eddies, with characteristic spatial scales of 10 -

$17100 \mathrm{~km}$ and temporal scales of weeks to months, and at the scale of submesoscale 18 dynamics contributes significantly to global carbon budgets (Levy, 2007). However, 19 because of the costs and logistics involved in sampling high frequency events in the 20 open ocean, direct observations at submesoscale range are scarce (Strass, 1992).

21 Previous studies have reported some evidence of variability in respiration rates associated with different types of mesoscale features. Enhanced respiration rates have 23 been associated with anticyclonic eddies in the Canary Islands region (Aristegui and 24 Montero, 2005). In the NE subtropical Atlantic several observations have reported net 25 autotrophic balances associated with cyclonic eddies as result of a reduction in 
1 respiration rates (Gonzalez et al., 2001; Maixandeau et al., 2005). In the summer of

2 2004, during the first year of field work of the Eddy Dynamics, Mixing Export, and

3 Species composition (EDDIES) project, an important variability in gross

4 photosynthesis and respiration rates was reported associated with three mesoscale

5 eddies investigated in the Sargasso Sea (Mourino-Carballido and McGillicuddy, 2006).

6 In this study I combine nine years $(1993$ - 2002) of altimeter data with data from the

7 BATS program in order to verify the hypothesis that respiration is as variable as

8 photosynthesis and equally influenced by (sub)mesoscale dynamics. 


\section{Methods}

2 Retrospective analysis of altimeter and BATS data

3 Eddy field animations for the $1993-2002$ period generated from the objective

4 analysis of satellite altimetry for the domain spanning latitude $28^{\circ}$ to $38^{\circ} \mathrm{N}$ and

5 longitude of $75^{\circ}$ to $45^{\circ} \mathrm{W}$ (available at

6 http://science.whoi.edu/users/mcgillic/tpd/anim.html) combined with hydrographic

7 profiles at BATS $\left(31.16^{\circ} \mathrm{N}-64.5^{\circ} \mathrm{W}\right)$ were used to assess the influence of the three

8 eddy types described in the Sargasso Sea: cyclones, anticyclones, and mode water

9 eddies (McGillicuddy et al., 1999), and frontal regions of interaction between cyclones

10 and anticyclonic eddies (CA) as described in Mouriño-Carballido and McGillicuddy

11 (2006). Other types of (sub)mesoscale activity that sporadically affect the BATS site

12 were not considered. Only those features that exhibited a strong signal and affected the

13 BATS site for relatively long periods of time were included in the analysis. This study

14 extends the retrospective analysis included in Mouriño-Carballido and McGillicuddy

15 (2006) as: 1) All the CA were identified during the nine-year period (whereas only CA

16 associated with enhancements of net community production were included in Mouriño-

17 Carballido and McGillicuddy (2006)); 2) eddy field animations and hydrographic data

18 were used to identify BATS samplings influenced by the center of the eddy features and

19 those affected by eddy uplifting but not located at the eddy center.

20 BATS data from the same period (1993-2002) were also used to study

21 distributions of nitrate, phosphate, silicate, oxygen, particulate and dissolved organic

22 carbon (POC and DOC, respectively), particulate and dissolved organic nitrogen (PON

23 and DON), pigments, bacterial biomass, ${ }^{14} \mathrm{C}$ incorporation by phytoplankton $\left({ }^{14} \mathrm{C} \mathrm{PP}\right)$,

24 bacterial growth (BG) and vertical carbon flux from sediment traps $\left(\mathrm{C}_{\text {flux }}\right)$. Changes in

25 community structure composition were investigated by computing the percent 
1 chlorophyll-a contributed by different phytoplankton groups by using the algorithms

2 developed for the oligotrophic Pacific by Letelier et al. (1993) and previously used for 3 the BATS site (Boyd and Newton, 1999; Sweeney et al., 2003). Details of the BATS 4 sampling scheme, analytical methods, data quality control, and inter-calibration 5 procedures appear in the BATS Methods Manual (Knap et al., 1993). Data are available

6 from the BATS web site at http://bats.bios.edu/. After much deliberation following 7 different tries with depth intervals, depth range selection was based on the vertical 8 distribution of properties at BATS site (Steinberg et al., 2001). Rates were integrated 9 down to the depth of the euphotic layer (ca. $100 \mathrm{~m}$ ). Percent chlorophyll-a contributed 10 by different phytoplankton groups was integrated deeper $(0-160 \mathrm{~m})$, to cover the deep

11 chlorophyll maximum feature. The deeper level of the sediment traps deployments at 12 BATS $(300 \mathrm{~m})$ was chosen to quantify the export of carbon from the upper layer. All 13 the other parameters were integrated down to the winter mixed layer depth (ca. $200 \mathrm{~m}$ ).

14 One-way analysis of variance (one-way ANOVA) was used to compare parameters 15 between different mesoscale features (cyclones, anticyclones, MWE and CA).

Indirect estimates of NCP (NCPe) derived from BATS data Indirect estimates of NCP (NCPe) for the 1993 - 2002 period were calculated 19 according to:

$$
\mathrm{NCPe}={ }^{14} \mathrm{CPP}-\mathrm{BR}
$$

22 where ${ }^{14} \mathrm{C} \mathrm{PP}$ is the rate of ${ }^{14} \mathrm{C}$ incorporation by phytoplankton (particulate primary production) and $\mathrm{BR}$ is bacterial respiration. $\mathrm{BR}$, in turn was estimated as:

$$
\mathrm{BR}=(\mathrm{BG} \times \mathrm{ICF} \times \mathrm{CCF}) \times\left(\frac{1}{\mathrm{BGE}}-1\right)
$$


1 where $\mathrm{BG}$ is bacterial growth rate measured by the $\{3 \mathrm{H}$-methyl $\}$-thymidine $\left({ }^{3} \mathrm{H}-\mathrm{TdR}\right)$

2 technique (Steinberg et al., 2001). Thymidine incorporation was converted to bacterial

3 respiration using the commonly reported isotope (ICF, $1.5 \times 10^{18} \mathrm{cell} \mathrm{mol}^{-1}$ ) and carbon

4 conversion factors (CCF, $15 \mathrm{fgC} \mathrm{cell}^{-1}$ ) (Ducklow, 2000), and the mean bacterial

5 growth efficiency (BGE) reported for the Sargasso Sea (ca. 0.13) (Carlson and

6 Ducklow, 1996). This value is higher than more recent BGE reported for open ocean

7 regions (0.08, Robinson et al., (In press)). However, I used the BGE reported by

8 Carlson and Ducklow (1996) because it derives from experiments carried out in the

9 same location as the study presented here. Mouriño-Carballido and McGillicuddy

10 (2006) applied a similar approach but they used bacterial carbon demand instead of BR.

11 It is known that the conversion factors involved in the calculation of BR from

12 BG are currently poorly constrained (Alonso-Saez et al., 2007). In this study, in order to

13 investigate the effect of a constant BGE in the variability reported for bacterial

14 respiration, I also computed BR using the empirical BGE models reported by del

15 Giorgio and Cole (1998), being BP bacterial production:

$$
\mathrm{BGE}_{1}=\left(\frac{0.037+0.65 \mathrm{BP}}{1.8+\mathrm{BP}}\right)
$$

and López-Urrutia \& Morán (2007):

$$
\mathrm{BGE}_{2}=\left(1-\frac{1}{0.727 \times \frac{\mathrm{chl}}{\mathrm{chl}+4.08}+1.02}\right)
$$

25 where chl is the chlorophyll concentration in $\mathrm{mg} \mathrm{m}^{-3}$. 
1 There are two important caveats associated with my estimates of NCP. First the

$2{ }^{14} \mathrm{C}$ assimilation technique underestimates gross primary production, and second 3 estimating respiration on the basis of BR underestimates total respiration. Compilation

4 of measurements carried out during the Joint Global Ocean Flux Study (JGOFS)

5 indicated that ${ }^{14} \mathrm{C}$ uptake measures net primary production (gross primary production -

6 autotrophic respiration) in dawn-dusk incubations (Marra, 2002). Within the euphotic

7 zone, the existing data further suggest that bacteria are the main contributors to

8 community respiration ( $\sim 50$ to $>90 \%$ ) (Rivkin and Legendre, 2001; Robinson and

9 Williams, 2005). Giorgio and Duarte (2002) reviewed the current information on the

10 contribution of various biotic components and depth layers to respiration in the open

11 ocean and they assumed that zooplankton respiration represents $5 \%$ of the combined

12 microplankton respiration in the photic and thermocline waters. Mesozooplankton

13 production at BATS has been estimated to be $2 \%$ of primary production at this site

14 (Roman et al., 2002). Unfortunately, the contribution of bacteria to community

15 respiration cannot be verified at this site since specific studies about the contribution of

16 microzooplancton respiration, and their variability, have not been conducted. 


\section{$1 \quad$ Results and discussion}

2 The variability of respiration versus photosynthesis

3 To determine whether the high variability observed in gross photosynthesis and

4 respiration rates during the EDDIES cruises is a common pattern in this region, I

5 compared depth integrated ${ }^{14} \mathrm{C}$ primary production (PP) and bacterial respiration (BR)

6 rates computed for the 1993-2002 period at the BATS site (Figure 1). To compute

7 bacterial respiration, I used the mean bacterial growth efficiency (BGE), 0.13, reported

8 for the Sargasso Sea by Carlson and Ducklow (1996). Mean values of BGE computed

9 by using the empirical models reported by del Giorgio and Cole (1998) $\left(\mathrm{BGE}_{1}=0.026 \pm\right.$

10 0.005) and López-Urrutia \& Morán (2007) $\left(\mathrm{BGE}_{2}=0.05 \pm 0.01\right)$ (see methods) were

11 much lower than the mean BGE value reported for the open ocean $(0.08$, Robinson et

12 al., (In press)), which results in high, and probably unrealistic, rates of BR (Figure 1).

13 Both empirical models were built from relatively limited data sets culled from diverse

14 ecosystems and they may not be adequate for all environments. No specific empirical

15 models have been reported for highly dynamic ocean ecosystems under the influence of

16 (sub)mesoscale processes. For this reason I decided to use a constant BGE in the

17 estimation of BR and NCPe. This is in agreement with the recent synthesis carried out

18 by Robinson (In press) who reports a median value of $6 \mathrm{mg} \mathrm{C} \mathrm{m}^{-3} \mathrm{~d}^{-1}$ for open ocean

19 BR.Variability in depth-integrated BR (reported as the coefficient of variation),

20 computed using $\mathrm{BGE}=0.013$ (Carlson and Ducklow, 1996), $\mathrm{BGE}_{1}$ and $\mathrm{BGE}_{2}$ was

21 always similar to or higher than variability in depth-integrated PP (Figure 1). Robinson

22 \& Williams (2005) analyzed a large data set of oxygen flux derived gross production

23 and respiration rates available in diverse ocean ecosystems. They reported the variance

24 of photosynthesis to be greater than respiration when volumetric rates computed at

25 different depths were used. However, they found similar variances in photosynthesis 
1 and respiration when they analyzed depth-integrated rates, which are better predictors

2 when regional or temporal differences between stations are analyzed, as they overcome

3 potential separation in depth of photosynthesis and respiration (Robinson and Williams, $42005)$.

6 The contribution of mesoscale dynamics to the observed variability in respiration

7 An important part of the variability observed in the primary production rates 8 measured at BATS has been previously attributed to mesoscale eddies (Sweeney et al., 9 2003). To investigate how much of the variability in bacterial respiration was driven by 10 (sub)mesoscale forcing, I tracked mesoscale eddies and frontal regions between 11 cyclones and anticyclones, using altimeter and hydrographic data from the BATS 12 station, over the 9-year period. Thirteen cyclones, six anticyclones, $8 \mathrm{MWE}$, and 17 13 frontal regions of interaction between cyclonic and anticyclonic eddies (CA) were 14 identified during the 1993 - 2002 period (see Figure 2 and table 1). Cyclones were the 15 (sub)mesoscale features that more frequently affected the area $(28 \%$ of the samplings 16 were affected by these features), followed by CA (23\%), MWE (13\%) and anticyclones $17(8 \%)$.

18 The impact of the (sub)mesoscale features on PP, BR, and NCPe, is more 19 noticeable when the seasonal signal in these parameters (see Figure 8 in Mouriño20 Carballido and McGillicuddy (2006)) is filtered out by computing anomalies relative to 21 monthly averages (Figure 3). Anomalies are rescaled to values between 1 and 10, where 2210 is the largest value for each parameter. Positive (negative) values represent 23 enhancements (decreases) with respect to typical background conditions for the 24 sampling month. It is important to bear in mind that this region is populated by closely 25 packed eddies that are constantly evolving and interacting with each other (Cianca et al., 
1 2007). As such, background conditions (anomalies close to zero) represent the mean

2 stage that results from the influence of the different types of mesoscale features 3 affecting this region. The anomaly record shows pulses in the magnitude of both PP and

4 BR, some of them in close connection with the (sub)mesoscale field. The use of

5 different parameterizations in the calculation of BGE (see methods) does not have a

6 significant effect on the variability in BR and the connection with the (sub)mesoscale

7 field (Figure 3). Nine out of the eighteen large (>2.5) NCPe anomalies occur during

8 periods when BATS is influenced by CA, four are associated with cyclonic eddies, two

9 with MWE, and one with an anticyclone. Six out of the nine high NCPe anomalies

10 found at CA are associated with small negative $(<-2.5)$ anomalies in BR.

11 The fixed-point time-series data generated by BATS create some inherent

12 difficulties to compare statistically the effects among eddy types. The impact of the

13 mesoscale forcing on the upper-ocean biochemistry at BATS includes variability

14 induced by the type of the mesoscale eddy, the section of the mesoscale eddy going

15 through the site (i.e. center versus edge), and also the variability induced by the stage of

16 the biological response (i.e. initial versus decaying stage). These factors are expected to

17 impact the robustness of statistics calculated from the time-series, in the sense that very

18 long time series would be needed in order to have a representative number of the

19 different stages. However, interesting patterns arise when the seasonal signal of several

20 biogeochemical parameters sampled at BATS site along the 1993 - 2002 period

21 (Steinberg et al., 2001) is filtered by means of anomalies with respect to monthly

22 averages, and when these anomalies are grouped based on the influence of cyclones,

23 anticyclones, MWE, and CA (Figure 4). Again, positive (negative) values represent

24 enhancements (decreases) relative to typical background conditions for the sampling 25 month. 
$1 \quad \mathrm{CA}$ are the (sub)mesoscale features associated with the highest anomaly in

$2 \mathrm{NCPe}$, as a result of relative enhanced PP and a strong reduction in BR (Figure 4).

3 These features are also characterized by a decrease of nitrate, consistent with nutrient

4 consumption though photosynthesis, and the increase of oxygen anomaly and

5 particulate organic carbon (POC) in the upper $200 \mathrm{~m}$. Plankton community composition

6 is characterised by the dominance of Prochlorococcus and Synechococcus and a slight

7 decrease in bacterial biomass. The lowest NCPe anomaly is found in anticyclonic

8 eddies, as a result of a substantial increase in BR. These features are also characterized

9 by an increase in nitrate and silicate, a decrease in oxygen anomaly and POC and a

10 noticeable enhancement in bacterial biomass in the upper $200 \mathrm{~m}$. Cyclones and MWE

11 are initially both associated with negative anomalies in NCPe.

12 However, substantial differences between both features arise when the BATS

13 samplings are divided into those influenced by the center of the eddy features and those

14 affected by eddy uplifting but not located at the eddy center (Ce and MWEe). Centers of

15 MWE are characterized by a noticeable increase in NCPe rates, as a result of the

16 estimated enhancement in PP. Drops in nitrate and silicate concentration, consistent

17 with nutrient consumption, as well as enhancements in oxygen anomaly, POC and

18 dissolved organic carbon (DOC) in the upper $200 \mathrm{~m}$ are also associated with the center

19 of MWE. Phytoplankton composition is dominated by dinoflagellates and a conspicuous

20 increase in diatoms, whereas bacterial biomass is noticeably reduced. An increase in

21 bacterial respiration is observed at MWEe, where bacterial biomass is slightly

22 enhanced. Centers of cyclonic eddies are associated with low NCPe values, as the result

23 of a noticeable increase in BR. Enhanced nitrate and silicate concentrations, but also

24 oxygen anomaly, and relatively reduced POC and DOC in the upper $200 \mathrm{~m}$ are

25 associated with these features. Plankton composition is dominated by Prochlorococcus 
1 and Synechococcus and slightly enhanced bacterial biomass. In agreement with the

2 patterns observed in $\mathrm{NCPe}$, higher carbon flux inferred from sediment traps was

3 observed at the center of MWE, whereas the lowest carbon flux was computed at the

4 center of cyclonic eddies. Differences between particular eddy types are statistically

5 significant for oxygen anomaly $(\mathrm{p}=0.015)$, diatom abundance $(\mathrm{p}=0.021)$, and net

6 community production $(\mathrm{p}=0.011)$, once the distinction of those samplings influenced by

7 eddy center and those affected by eddy uplifting but not located at the eddy center is

8 made (see Table 2).

9 This study confirms previous results regarding differences between eddy types.

10 The analysis of three years of data (1993-1995) from the BATS site reported noticeable

11 enhancements in primary production associated with two MWE, whereas the 1994

12 spring bloom was suppressed by the passage of an anticyclone (Sweeney et al., 2003).

13 The same authors described an increased percentage of diatoms and dinoflagellates in

14 MWE, whereas cyclones exhibited an increased percentage of Synechococcus. The

15 pattern described in this study in anticyclones and $\mathrm{CA}$ is in agreement with in vitro

16 gross photosynthesis and respiration rates reported in summer 2004 by Mouriño-

17 Carballido and McGillicuddy (2006). The variability reported inside the cyclone

18 intensively investigated in summer 2004 (C1) highlights the relevance of considering

19 the time history of mesoscale eddies when interpreting the biological responses

20 associated with these features. For this reason, patterns observed at each eddy feature

21 from the retrospective analysis of the BATS data should be considered cautiously as

22 they may not include a representative number of all the possible eddy life stages. In

23 agreement with the retrospective analysis of BATS data presented in this study,

24 plankton composition was dominated by Prochlorococcus spp. in cyclone $\mathrm{C} 1$ whereas a

25 diatom bloom was found in MWE A4, the mode water eddy investigated in summer 
12005 (McGillicuddy et al., 2007). Based on the assumption that the $\mathrm{O}_{2}$ minimum found

2 in the central eddy stations at C1 (200-400 m) and A4 (800-1000 m) was a consequence

3 of high particle export from eddy induced blooms, carbon export inferred from the $\mathrm{O}_{2}$

4 anomalies was one to three times as much as annual new production for the region

5 (McGillicuddy et al., 2007). The retrospective analysis from the BATS data show a

6 noticeably enhanced deep (200-800 m) oxygen anomaly associated with the center of

7 MWE (see Table 2). Other depth intervals (200-400 m, 400-600 m and 600-800 m)

8 show similar results (data not shown). However, the BATS sampling probably misses

9 the smaller and more variable $\mathrm{O}_{2}$ anomalies found at $\mathrm{C} 1$ and $\mathrm{A} 4$ cores. Modeling

10 experiments based on the results from summer 2004 and 2005 EDDIES cruises suggest

11 that diatom blooms are sustained by interactions with the surface wind field at MWE,

12 whereas wind-eddy interactions dampen upwelling in cyclones (McGillicuddy et al.,

13 2007). Details on the mechanisms responsible for the reduced bacterial respiration

14 described at CA remain unknown. The influence of changes in bacterial populations

15 associated with different hydrodynamic regimes (Morris et al., 2005) can not be 16 discounted.

\section{Conclusions}

19 Respiration represents the largest sink of organic carbon in the biosphere. On a

20 global scale, excluding external sources of organic matter (Dachs et al., 2005),

21 respiration must be balanced by the input of organic matter via autotrophic production.

22 Based on the assumption of its relative constancy, respiration has the potential to be a

23 more accurate measure of time-integrated net organic production than photosynthesis,

24 particularly for under-sampled, highly dynamic systems (Carlson et al., 2007). My

25 results show for the first time that, contrary to previous assumptions, in highly dynamic 
1 ecosystems influenced by (sub)mesoscale dynamics, respiration can be as variable as

2 photosynthesis. Pulses in respiration driven by (sub)mesoscale forcing need to be

3 considered in order to quantify the balance between synthesis and consumption of

4 organic matter. Future sampling strategies should be designed in order to resolve

5 higher-frequency, smaller-scale variability in both photosynthesis and respiration,

6 which is crucial to comprehend the potential for carbon export to the deep ocean.

\section{Acknowledgments}

9 I am grateful to people involved in the collection, preparation and analysis of the data 10 from the BATS program. I thank D. McGillicuddy and V. Kosnyrev for the elaboration 11 and public access of the dynamical interpolation of mesoscale flows in the 12 Topex/Poseidon diamond surrounding the BATS site. I am also grateful to X. Irigoien, 13 E. Marañón, S. Neuer, T. Bibby, F. Tapia, X.A. Morán, K. Buesseler \& the Café 14 Thorium for their valuable comments on this manuscript. Comments by three 15 anonymous reviewers are also acknowledged. I was supported by a Fulbright 16 postdoctoral fellowship and the Juan de la Cierva program from the Spanish Ministry of

17 Science and Education. Support of this activity by the U.S. National Science Foundation 18 and the National Aeronautics and Space Administration is greatly appreciated. 


\section{References}

2 Alonso-Saez, L., Gasol, J.M., Aristegui, J., Vilas, J.C., Vaque, D., Duarte, C.M. and 3 Agusti, S., 2007. Large-scale variability in surface bacterial carbon demand and 4 growth efficiency in the subtropical northeast Atlantic Ocean. Limnology and $5 \quad$ Oceanography, 52(2): 533-546.

6 Aristegui, J. and Montero, M.F., 2005. Temporal and spatial changes in plankton 7 respiration and biomass in the Canary Islands region: the effect of mesoscale 8 variability. Journal of Marine Systems, 54(1-4): 65-82.

9 Balkanski, Y., Monfray, P., Battle, M. and Heimann, M., 1999. Ocean primary 10 production derived from satellite data: An evaluation with atmospheric oxygen 11 measurements. Global Biogeochemical Cycles, 13(2): 257-271.

12 Bender, M., Orchardo, J., Dickson, M.L., Barber, R. and Lindley, S., 1999. In vitro O-2 fluxes compared with $\mathrm{C}-14$ production and other rate terms during the JGOFS Equatorial Pacific experiment. Deep-Sea Research Part I-Oceanographic Research Papers, 46(4): 637-654.

Boyd, P.W. and Newton, P.P., 1999. Does planktonic community structure determine downward particulate organic carbon flux in different oceanic provinces? Deep Sea Research Part I: Oceanographic Research Papers, 46(1): 63-91.

Carlson, C., Del Giorgio, P.A. and Herndl, G.J., 2007. Microbes and the dissipation of energy and repiration: from cells to ecosystems. Oceanography, 20(2): 89-100.

Carlson, C.A. and Ducklow, H.W., 1996. Growth of bacterioplankton and consumption of dissolved organic carbon in the Sargasso Sea. Aquatic Microbial Ecology, 10(1): 69-85.

24 Cianca, A., Helmke, P., Mourino, B., Rueda, M.J., Llinas, O., and Neuer, S. 2007. Decadal analysis of hydrography and in situ nutrient budgets in the western and 
eastern North Atlantic subtropical gyre. Journal of Geophysical Research, C, Oceans, 112, C07025, doi:10.1029/2006JC003788.

Dachs, J., Calleja, M.L., Duarte, C.M., del Vento, S., Turpin, B., Polidori, A., Herndl, G.J. and Agusti, S. 2005. High atmosphere-ocean exchange of organic carbon in the NE subtropical Atlantic. Geophysical Research Letters, 32(21), L21807, doi:10.1029/2005GL023799.

del Giorgio, P.A. and Cole, J.J., 1998. Bacterial growth efficiency in natural aquatic systems. Annual Review of Ecology and Systematics, 29: 503-541.

del Giorgio, P.A. and Duarte, C.M., 2002. Respiration in the open ocean. Nature, 420(6914): 379-384.

Duarte, C.M., Agustí, S., A., d.G.P. and J., C.J., 1999. Regional carbon imbalances in the oceans. Response. Science, 284: $1735 b$.

Ducklow, H.W., 2000. Bacterial production and biomass in the oceans. In: D.L. Kirchman (Editor), Microbial ecology of the oceans. A. John Wiley \& Sons, Inc.

Eppley, R.W., Renger, E.H., Venrick, E.L. and Mullin, M.M., 1973. Study of Plankton Dynamics and Nutrient Cycling in Central Gyre of North Pacific Ocean. Limnology \& Oceanography, 18: 534-551.

Gonzalez, N., Anadon, R., Mourino, B., Fernandez, E., Sinha, B., Escanez, J., de Armas, D. 2001. The metabolic balance of the planktonic community in the North Atlantic Subtropical Gyre: The role of mesoscale instabilities. Limnology and Oceanography, 46(4): 946-952.

Hansell, D.A., Ducklow, H.W., Macdonald, A.M. and Baringer, M.O., 2004. Metabolic poise in the North Atlantic Ocean diagnosed from organic matter transports. Limnology and Oceanography, 49(4): 1084-1094. 
1 Karl, D.M., Hebel, D.V., Bjorkman, K. and Letelier, R.M., 1998. The role of dissolved

4 Karl, D.M., Laws, E.A., Morris, P., Williams, P.J.1. and Emerson, S., 2003. Global organic matter release in the productivity of the oligotrophic North Pacific Ocean. Limnology and Oceanography, 43(6): 1270-1286. carbon cycle - Metabolic balance of the open sea. Nature, 426(6962): 32.

Knap, A.H., Michaels, A.F., Dow, R.L., Johnson, R.J., Gundersen, K., Sorensen, J.C., Close, A., Howse, F., Hammer, M., Bates, N.R., Doyle, A. and Waterhouse, T. 1993. BATS methods Manual, Version 3. US JGOFS Planning Office, Woods Hole, MA, USA.

Laws, E.A., Martin, A.P., Liddicoat, M.I., Watson, A.J., Richards, K.J. and Woodward, E. M.S., 2000. Carbon cycling in primary production bottle incubations: inferences from grazing experiments and photosynthetic studies using C-14 and O-18 in the Arabian Sea. Deep-Sea Research Part II-Topical Studies in Oceanography, 47(7-8): 1339-1352.

Letelier, R.M., Bidigare, R.R., Hebel, D.V., Ondrusek, M., Winn, C.D. and Karl, D.M., 1993. Temporal Variability of Phytoplankton Community Structure-Based on Pigment Analysis. Limnology and Oceanography, 38(7): 1420-1437.

Levy, M., 2008. The modulation of biological production by oceanic mesoscale turbulence, Transport and Mixing in Geophysical Flows. Springer Berlin / Heidelberg, pp. 219-261.

Lopez-Urrutia, A. and Moran, X.A.G., 2007. Resource limitation of bacterial production distorts the temperature dependence of oceanic carbon cycling. Ecology, 88(4): 817-822.

Maixandeau, A., Lefevre, D., Karayanni, H., Christaki, U., Van Wambeke, F., Thyssen, M., Denis, M., Fernandez, C.I., Uitz, J., Leblanc, K. and Queguiner, B. 2005. 
1 Microbial community production, respiration, and structure of the microbial

2 food web of an ecosystem in the northeastern Atlantic Ocean. Journal of 3 Geophysical Research-Oceans, 110(C7), C07S17, doi:10.1029/2004JC002694.

4 Maranon, E., Holligan, P.M., Varela, M., Mourino, B. and Bale, A.J., 2000. Basin-scale variability of phytoplankton biomass, production and growth in the Atlantic Ocean. Deep-Sea Research Part I-Oceanographic Research Papers, 47(5): 825857.

8 Marra, J., 2002. Approaches to the measurement of plankton production. In: P.J.1. 9 Williams, D.N. Thomas and C.S. Reynolds (Editors), Phytoplankton 10 productivity: Carbon assimilation in marine and freshwater ecosystems. 11 Blackwell Publishing, LTD, Cambridge, Blackwells, pp. 78-108.

12 McGillicuddy, D., Laurence A., Bates, N.R., Bibby, T., Buesseler, K.O., Carlson, C.A., 13 Davis, C.S., Ewart, C., Falkowski, P.G., Goldthwait, S.A., Hansell, D.A., 14 Jenkins, W.J., Johnson, R., Kosnyrev, V.K., Ledwell, J.R., Li, Q.P., Siegel, D.A. 15 and Steinberg, D.K.. 2007. Eddy/wind interactions stimulate extraordinary mid16 ocean plankton blooms. Science, 316( 5827): 1021-1026.

17 McGillicuddy, D.J., Johnson, R., Siegel, D.A., Michaels, A.F., Bates, N.R., Knap, A.H. 18 1999. Mesoscale variations of biogeochemical properties in the Sargasso Sea. 19 Journal of Geophysical Research-Oceans, 104(C6): 13381-13394.

20 Morris, R.M., Vergin, K.L., Cho, J.C., Rappe, M.S., Carlson, C.A., Giovannoni, S.J 21 2005. Temporal and spatial response of bacterioplankton lineages to annual 22 convective overturn at the Bermuda Atlantic Time-series Study site. Limnology 23 and Oceanography, 50(5): 1687-1696. 
1 Mourino-Carballido, B. and McGillicuddy, D.J., 2006. Mesoscale variability in the metabolic balance of the Sargasso Sea. Limnology and Oceanography, 51(6): 2675-2689.

4 Najjar, R.G. and Keeling, R.F., 2000. Mean annual cycle of the air-sea oxygen flux: A global view. Global Biogeochemical Cycles, 14(2): 573-584.

6 Riser, S.C. and Johnson, K.S., 2008. Net production of oxygen in the subtropical ocean. Nature, 451(7176): 323-325.

8 Rivkin, R.B. and Legendre, L., 2001. Biogenic Carbon Cycling in the Upper Ocean: 9 Effects of Microbial Respiration. Science, 291(5512): 2398-2400.

10 Robinson, A.R. and Williams, P.J.L., 2005. Respiration and its measurement in surface 11 marine waters. In: P.A. Del Giorgio and P.J.L. Williams (Editors), Respiration

Roman, M.R., Adolf, H.A., Landry, M.R., Madin, L.P., Steinberg, D.K., Zhang, X., 2002. Estimates of oceanic mesozooplankton production: a comparison using the Bermuda and Hawaii time-series data. Deep-Sea Research Part II-Topical Studies in Oceanography, 49(1-3): 175-192.

Steinberg, D.K., Carlson, C.A., Bates, N.R., Johnson, R.J., Michaels, A.F., Knap, A.H., 2001. Overview of the US JGOFS Bermuda Atlantic Time-series Study (BATS): a decade-scale look at ocean biology and biogeochemistry. Deep-Sea Research Part II-Topical Studies in Oceanography, 48(8-9): 1405-1447.

Strass, V.H., 1992. Chlorophyll Patchiness Caused by Mesoscale Upwelling at Fronts. Deep-Sea Research Part a-Oceanographic Research Papers, 39(1A): 75-96. 
1 Sweeney, E.N., McGillicuddy, D.J. and Buesseler, K.O., 2003. Biogeochemical impacts

2

3

4

5 Williams, P.J.B. and Del Giorgio, P.A., 2005. Respiration in aquatic ecosystems: history and background. In: P.A. Del Giorgio and P.J.B. Williams (Editors), Respiration in Aquatic Ecosystems. Oxford University Press, New York, pp. 117.

Williams, P.J.1., 1998. The balance of plankton respiration and photosynthesis in the open oceans. Nature, 394(6688): 55-57.

Williams, P.J.1. and Jenkinson, N.W., 1982. A Transportable Microprocessor-Controlled Precise Winkler Titration Suitable for Field Station and Shipboard Use. Limnology and Oceanography, 27(3): 576-584. 
Table 1. Details of mesoscale features identified at BATS site for the $1993-2002$ period. $\mathrm{C}$ is cyclone, A anticyclone and MWE mode water eddy. CA corresponds to areas of interaction between cyclone and anticyclone eddies. Beginning and end periods of mesoscale feature presence at BATS are indicated. Independent features were tracked back in time in order to determine their age at the time they influenced BATS sampling.

\begin{tabular}{|c|c|c|c|c|}
\hline Number & Type & $\begin{array}{c}\text { Influence at BATS } \\
\text { (begining) }\end{array}$ & $\begin{array}{c}\text { Influence at BATS } \\
\text { (end) }\end{array}$ & Age (months) \\
\hline 1 & $\mathrm{C}$ & 12 Jan 1993 & 11 Feb 1993 & 3 \\
\hline 2 & MWE & 27 Apr 1993 & 11 May 1993 & 1 \\
\hline 3 & $\mathrm{C}$ & 13 Jun 1993 & 16 Jul 1993 & 2 \\
\hline 4 & A & 17 Aug 1993 & 14 Oct 1993 & 7 \\
\hline 5 & $\mathrm{C}$ & 8 Nov 1993 & 12 Nov 1993 & 11 \\
\hline 6 & $\mathrm{CA}$ & 6 Dec 1993 & 18 Jan 1994 & \\
\hline 7 & $\mathrm{~A}$ & 15 Feb 1994 & 21 Mar 1994 & 2.5 \\
\hline 8 & $\mathrm{CA}$ & 5 Apr 1994 & 20 May 1994 & \\
\hline 9 & $\mathrm{C}$ & 18 Jul 1994 & 19 Aug 1994 & 2 \\
\hline 10 & A & 19 Sep 1994 & 21 Oct 1994 & \\
\hline 11 & $\mathrm{C}$ & 14 Nov 1994 & 13 Jan 1995 & \\
\hline 12 & $\mathrm{CA}$ & 1 Mar 1995 & 16 Mar 1995 & \\
\hline 13 & $\mathrm{C}$ & 29 Mar 1995 & 27 Apr 1995 & \\
\hline 14 & $\mathrm{CA}$ & 10 May 1995 & 13 May 1995 & \\
\hline 15 & MWE & 12 Jun 1995 & 22 Aug 1995 & 1 \\
\hline 16 & MWE & 12 Sep 1995 & 11 Nov 1995 & \\
\hline 17 & $\mathrm{C}$ & 30 Jan 1996 & 16 Mar 1996 & 6 \\
\hline 18 & $\mathrm{CA}$ & 8 Apr 1996 & 13 Apr 1996 & \\
\hline 19 & $\mathrm{CA}$ & 3 Sep 1996 & 5 Sep 1996 & \\
\hline 20 & MWE & 8 Oct 1996 & 13 Nov 1996 & \\
\hline 21 & $\mathrm{CA}$ & 12 Dec 1996 & 14 Dec 1996 & \\
\hline 22 & $\mathrm{C}$ & 13 Jan 1997 & 19 Mar 1997 & \\
\hline 23 & $\mathrm{CA}$ & 8 Apr 1997 & 9 Apr 1997 & \\
\hline 24 & MWE & 5 May 1997 & 8 May 1997 & 4 \\
\hline 25 & MWE & 11 Aug 1997 & 8 Oct 1997 & \\
\hline 26 & A & 12 Nov 1997 & 12 Dec 1997 & \\
\hline 27 & $\mathrm{C}$ & 11 Feb 1998 & 13 Mar 1998 & \\
\hline 28 & $\mathrm{CA}$ & 6 Jul 1998 & $10 \mathrm{Jul} 1998$ & \\
\hline 29 & A & 8 Sep 1998 & 11 Sep 1998 & \\
\hline 30 & $\mathrm{CA}$ & 8 Dec 1998 & 11 Dec 1998 & \\
\hline 31 & $\mathrm{C}$ & 14 Jan 1999 & 27 Jan 1999 & 5.5 \\
\hline 32 & $\mathrm{CA}$ & 11 Feb 1999 & 13 Feb 1999 & \\
\hline 33 & A & 24 Feb 1999 & 24 Feb 1999 & \\
\hline 34 & $\mathrm{CA}$ & 7 Apr 1999 & 9 Apr 1999 & \\
\hline 35 & $\mathrm{C}$ & 1 Jun 1999 & 9 Jul 1999 & 6.5 \\
\hline 36 & $\mathrm{CA}$ & 2 Aug 1999 & 12 Nov 1999 & \\
\hline 37 & $\mathrm{C}$ & 14 Mar 2000 & 13 Apr 2000 & \\
\hline 38 & $\mathrm{CA}$ & 9 Jun 2000 & 9 Aug 2000 & \\
\hline 39 & MWE & 11 Sep 2000 & 21 Oct 2000 & \\
\hline 40 & $\mathrm{CA}$ & 13 Nov 2000 & 17 Nov 2000 & \\
\hline 41 & $\mathrm{C}$ & 30 Jan 2001 & 20 Apr 2001 & \\
\hline 42 & $\mathrm{CA}$ & 14 May 2001 & 18 Aug 2001 & \\
\hline 43 & $\mathrm{CA}$ & 9 Oct 2001 & 13 Nov 2001 & \\
\hline 44 & MWE & 11 Dec 2001 & 15 Dec 2001 & \\
\hline
\end{tabular}


Table 2. Anomalies for selected parameters computed with respect to monthly averages for the $1993-2002$ period at BATS site. Depth integration intervals are shown. C, A, and MWE correspond to cyclones, anticyclones and mode water eddies, respectively (c, center; e, edge). CA corresponds to cyclones - anticyclones interactions. $\Delta \mathrm{O}_{2}$, is oxygen anomaly $\left(\mathrm{O}_{2}\right.$ in situ $-\mathrm{O}_{2}$ saturation); POC (DOC) is particulate (dissolved) organic carbon; PON (DON) is particulate (dissolved) organic nitrogen. Prochlorococcus, Synechococcus prymnesiophytes, prasinophytes, pelagophytes, dinoflagellates and diatoms represent the percent chlorophyll-a contributed by these groups. PP, primary production; BR, bacterial respiration (computed assuming $\mathrm{BGE}=0.13$ ); NCPe, net community production. $\mathrm{C}_{\text {flux }}$ is carbon flux estimated from sediment traps. The STD is standard deviation; $p$ statistic probability, $\mathrm{n}$ number of samples. The multiple comparison Bonferroni test was applied a posteriori to analyse the differences between every pair of groups.

\begin{tabular}{|c|c|c|c|c|c|c|c|c|c|c|c|c|c|c|c|c|c|}
\hline Variable (units) & $\begin{array}{c}\mathrm{C} \\
\text { Mean } \\
\pm \text { STD } \\
\end{array}$ & $\mathrm{n}$ & $\begin{array}{c}\mathrm{Cc} \\
\text { Mean } \\
\pm \text { STD } \\
\end{array}$ & $\mathrm{n}$ & $\begin{array}{c}\mathrm{Ce} \\
\text { Mean } \\
\pm \text { STD } \\
\end{array}$ & $\mathrm{n}$ & $\begin{array}{c}\text { A } \\
\text { Mean } \\
\pm \text { STD } \\
\end{array}$ & $\mathrm{n}$ & $\begin{array}{l}\text { MWE } \\
\text { Mean } \\
\pm \text { STD } \\
\end{array}$ & $\mathrm{n}$ & $\begin{array}{c}\text { MWEc } \\
\text { Mean } \\
\pm \text { STD } \\
\end{array}$ & $\mathrm{n}$ & $\begin{array}{c}\text { MWEe } \\
\text { Mean } \\
\pm \text { STD } \\
\end{array}$ & $\mathrm{n}$ & $\begin{array}{c}\text { CA } \\
\text { Mean } \\
\pm \text { STD } \\
\end{array}$ & $\mathrm{n}$ & $\begin{array}{c}\text { One way } \\
\text { ANOVA } \\
p \text {-value }\end{array}$ \\
\hline Nitrate $(0-200 \mathrm{~m})\left(\mathrm{mmol} \mathrm{m}^{-2}\right)$ & $12 \pm 62$ & 37 & $5 \pm 38$ & 6 & $13 \pm 66$ & 31 & $6 \pm 44$ & 12 & $-8 \pm 63$ & 15 & $-44 \pm 48$ & 2 & $-2 \pm 64$ & 13 & $-25 \pm 61$ & 29 & 0.224 \\
\hline Phosphate $(0-200 \mathrm{~m})\left(\mathrm{mmol} \mathrm{m}^{-2}\right)$ & $1 \pm 4$ & 36 & $2 \pm 2$ & 6 & $1 \pm 4$ & 30 & $1 \pm 3$ & 12 & $-1 \pm 5$ & 15 & $-4 \pm 1$ & 2 & $0 \pm 5$ & 13 & $-1 \pm 4$ & 29 & 0.281 \\
\hline Silicate $(0-200 \mathrm{~m})\left(\mathrm{mmol} \mathrm{m}^{-2}\right)$ & $8 \pm 51$ & 37 & $45 \pm 23$ & 6 & $0 \pm 52$ & 31 & $13 \pm 27$ & 12 & $-4 \pm 65$ & 16 & $-17 \pm 69$ & 3 & $-1 \pm 67$ & 13 & $1 \pm 73$ & 29 & 0.706 \\
\hline$\Delta \mathrm{O}_{2}(0-200 \mathrm{~m})\left(\mathrm{mmol} \mathrm{m}^{-2}\right)$ & $-70 \pm 601$ & 38 & $266 \pm 460$ & 6 & $-133 \pm 609$ & 32 & $-207 \pm 700$ & 12 & $431 \pm 492$ & 17 & $874 \pm 683$ & 4 & $295 \pm 347$ & 13 & $85 \pm 686$ & 31 & $\begin{array}{c}0.015^{*} \\
\mathrm{MWEc}>\mathrm{Ce}, \mathrm{A}\end{array}$ \\
\hline$\Delta \mathrm{O}_{2}(200-800)\left(\mathrm{mmol} \mathrm{m}^{-2}\right)$ & $-2883 \pm 4311$ & 26 & $-4856 \pm 2517$ & 4 & $-2524 \pm 4615$ & & $1721 \pm 4670$ & 9 & $5706 \pm 5552$ & 15 & $9214 \pm 9899$ & 3 & $4830 \pm 4149$ & 12 & $-1165 \pm 3902$ & 25 & $\begin{array}{c}<0.001^{* *} \\
\mathrm{MWE}>\mathrm{C}, \mathrm{CA}\end{array}$ \\
\hline POC $(0-200 \mathrm{~m})\left(\mathrm{ug} \mathrm{m}^{-2}\right)$ & $-104 \pm 1149$ & 36 & $-107 \pm 1105$ & 6 & $-104 \pm 1176$ & 30 & $-124 \pm 510$ & 11 & $300 \pm 780$ & 17 & $691 \pm 1420$ & 4 & $180 \pm 491$ & 13 & $279 \pm 881$ & 31 & 0.428 \\
\hline $\operatorname{DOC}(0-200 \mathrm{~m})\left(\mathrm{ug} \mathrm{m}^{-2}\right)$ & $-124 \pm 428$ & 27 & $-103 \pm 238$ & 4 & $-128 \pm 457$ & 23 & $11 \pm 415$ & 9 & $155 \pm 209$ & 12 & $364 \pm 234$ & 2 & $114 \pm 189$ & 10 & $25 \pm 470$ & 23 & 0.465 \\
\hline PON $(0-200 \mathrm{~m})\left(\mathrm{ug} \mathrm{m}^{-2}\right)$ & $-43 \pm 168$ & 36 & $14 \pm 73$ & 6 & $-54 \pm 180$ & 30 & $20 \pm 123$ & 11 & $26 \pm 147$ & 17 & $43 \pm 227$ & 4 & $21 \pm 126$ & 13 & $41 \pm 141$ & 31 & 0.349 \\
\hline $\operatorname{DON}(0-200 \mathrm{~m})\left(\mathrm{ug} \mathrm{m}^{-2}\right)$ & $-2 \pm 86$ & 26 & $-35 \pm 77$ & 5 & $6 \pm 88$ & 21 & $-28 \pm 47$ & 9 & $-19 \pm 47$ & 14 & $19 \pm 44$ & 3 & $-29 \pm 44$ & 11 & $23 \pm 81$ & 25 & 0.307 \\
\hline Prochlorococcus $(0-160 \mathrm{~m})(\%)$ & $1 \pm 6$ & 32 & $5 \pm 6$ & 6 & $0 \pm 6$ & 26 & $-2 \pm 10$ & 12 & $-2 \pm 15$ & 17 & $-5 \pm 15$ & 4 & $-2 \pm 16$ & 13 & $4 \pm 12$ & 26 & 0.167 \\
\hline Synechococcus $(0-160 \mathrm{~m})(\%)$ & $2 \pm 10$ & 32 & $5 \pm 8$ & 6 & $1 \pm 10$ & 26 & $-3 \pm 11$ & 12 & $-3 \pm 7$ & 17 & $-1 \pm 10$ & 4 & $-4 \pm 6$ & 13 & $7 \pm 27$ & 26 & 0.486 \\
\hline Prymnesiophytes (0-160 m) (\%) & $0 \pm 6$ & 32 & $-1 \pm 6$ & 6 & $1 \pm 6$ & 26 & $1 \pm 3$ & 12 & $-2 \pm 6$ & 17 & $1 \pm 9$ & 4 & $-3 \pm 5$ & 13 & $0 \pm 10$ & 26 & 0.895 \\
\hline Prasinophytes (0-160 m) (\%) & $0 \pm 3$ & 32 & $-1 \pm 1$ & 6 & $0 \pm 3$ & 26 & $-1 \pm 2$ & 12 & $0 \pm 2$ & 17 & $2 \pm 3$ & 4 & $-1 \pm 2$ & 13 & $1 \pm 5$ & 26 & 0.316 \\
\hline Pelagophytes (0-160 m) (\%) & $0 \pm 2$ & 32 & $-1 \pm 1$ & 6 & $0 \pm 3$ & 26 & $0 \pm 2$ & 12 & $1 \pm 4$ & 17 & $1 \pm 3$ & 4 & $0 \pm 4$ & 13 & $0 \pm 5$ & 26 & 0.973 \\
\hline Dinoflagellates $(0-160 \mathrm{~m})(\%)$ & $0 \pm 1$ & 32 & $0 \pm 1$ & 6 & $0 \pm 1$ & 26 & $0 \pm 1$ & 12 & $0 \pm 1$ & 17 & $1 \pm 2$ & 4 & $-1 \pm 1$ & 13 & $0 \pm 2$ & 26 & 0.137 \\
\hline Diatoms $(0-160 \mathrm{~m})(\%)$ & $0 \pm 2$ & 32 & $0 \pm 1$ & 6 & $0 \pm 2$ & 26 & $1 \pm 2$ & 12 & $2 \pm 6$ & 17 & $5 \pm 12$ & 4 & $1 \pm 3$ & 13 & $-1 \pm 2$ & 26 & $\begin{array}{c}0.030^{*} \\
\mathrm{MWEc}>\mathrm{Ce}, \mathrm{CA}\end{array}$ \\
\hline bacterial biomass $(0-200 \mathrm{~m})\left(\mathrm{mg} \mathrm{m}^{-2}\right)$ & $-2 \pm 197$ & 36 & $14 \pm 161$ & 6 & $-6 \pm 205$ & 30 & $78 \pm 75$ & 11 & $-5 \pm 97$ & 17 & $-57 \pm 83$ & 4 & $11 \pm 98$ & 13 & $-8 \pm 189$ & 31 & 0.722 \\
\hline $\operatorname{PP}(0-100 \mathrm{~m})\left(\mathrm{mgC} \mathrm{m}^{-2} \mathrm{~d}^{-1}\right)$ & $-49 \pm 141$ & 34 & $-94 \pm 60$ & 6 & $-40 \pm 152$ & 28 & $-10 \pm 136$ & 11 & $4 \pm 165$ & 17 & $121 \pm 222$ & 4 & $-33 \pm 134$ & 13 & $35 \pm 172$ & 29 & 0.147 \\
\hline $\operatorname{BR}(0-100 \mathrm{~m})\left(\mathrm{mgC} \mathrm{m}^{-2} \mathrm{~d}^{-1}\right)$ & $20 \pm 147$ & 34 & $109 \pm 220$ & 6 & $1 \pm 124$ & 28 & $64 \pm 134$ & 11 & $48 \pm 207$ & 17 & $-37 \pm 65$ & 4 & $74 \pm 230$ & 13 & $-55 \pm 158$ & 29 & 0.111 \\
\hline $\operatorname{NCPe}(0-100 \mathrm{~m})\left(\mathrm{mgC} \mathrm{m}^{-2} \mathrm{~d}^{-1}\right)$ & $-69 \pm 227$ & 34 & $-203 \pm 194$ & 6 & $-40 \pm 226$ & 28 & $-74 \pm 216$ & 11 & $-44 \pm 259$ & 17 & $158 \pm 181$ & 4 & $-106 \pm 251$ & 13 & $90 \pm 195$ & 29 & $\begin{array}{l}0.011^{*} \\
\mathrm{CA}>\mathrm{Cc}\end{array}$ \\
\hline Cflux $(0-300 \mathrm{~m})\left(\mathrm{g} \mathrm{m}^{-2} \mathrm{~d}^{-1}\right)$ & $0 \pm 2$ & 28 & $-1 \pm 1$ & 5 & $0 \pm 2$ & 23 & $0 \pm 2$ & 10 & $0 \pm 1$ & 16 & $0.3 \pm 0.4$ & 4 & $0 \pm 1$ & 12 & $0 \pm 1$ & 27 & 0.887 \\
\hline
\end{tabular}




\section{$1 \quad$ Figure legends}

2 Figure 1. Depth-integrated $(0-100 \mathrm{~m}){ }^{14} \mathrm{C}$ primary production versus depth-integrated 3 bacterial respiration (BR) estimated for the 1993-2002 period at the BATS site. BR was 4 calculated assuming a constant $\mathrm{BGE}=0.13(\mathrm{~A}) . \mathrm{BR}_{1}(\mathrm{~B})$ and $\mathrm{BR}_{2}(\mathrm{C})$ were computed using 5 the empirical models for BGE reported by del Giorgio and Cole (1998) and López-Urrutia

$6 \&$ Morán (2007) (see methods). Coefficient of variation for ${ }^{14} \mathrm{C} \mathrm{PP}, \mathrm{BR}, \mathrm{BR}_{1}$ and $\mathrm{BR}_{2}$ are 7 45, 66, 46 and 71\%, respectively. Median values for $\mathrm{BR}, \mathrm{BR}_{1}$ and $\mathrm{BR}_{2}$ are 226, 1238 and $8790 \mathrm{mgC} \mathrm{m}^{-2} \mathrm{~d}^{-1}$, respectively. The black lines are the 1:1 lines.

9 Figure 2. (A). Sea level anomalies (SLA) estimated for the 1993-2002 period at the BATS 10 site. (B) Temperature in the upper $700 \mathrm{~m}$ for the 1993 - 2002 period at BATS site. Coloured 11 bars indicate periods under the influence of cyclones (blue), anticyclones (red), mode water 12 eddies (yellow), and frontal regions between cyclonic and anticyclonic eddies (green). 13 White sections correspond to other type of (sub)mesoscale activity not included in this 14 analysis. Numbers on the top correspond to mesoscale features identified during the 9-year 15 period (see table 1).

16 Figure 3. Anomalies for depth-integrated $(0-100 \mathrm{~m})$ primary production $(\mathrm{PP})$, bacterial 17 respiration $(\mathrm{BR})$ and net community production $(\mathrm{NCPe})$ computed with respect to monthly 18 averages and rescaled to values between 1 and 10 for the $1993-2002$ period at BATS site. 19 Anomalies for BR computed assuming a constant BGE (0.13) (solid line), the empirical 20 model reported by del Giorgio and Cole (1998) (dashed line) and López-Urrutia \& Morán 21 (2007) (dotted line) are represented. Coloured bars indicate periods under the influence of 22 cyclonic (blue), anticyclonic (red), mode water eddies (yellow), and frontal regions between 23 cyclonic and anticyclonic eddies (green). White sections correspond to other type of 
1 (sub)mesoscale activity not included in this analysis (see methods). Horizontal dashed lines

2 indicates arbitrary thresholds in the 1-10 scale of 2.5 (i.e., $25 \%$ of the largest value) and -

32.5 (i.e., $-25 \%$ of the largest value). Numbers on the top correspond to mesoscale features

4 identified during the 9-year period (see table 1).

5 Figure 4. Anomalies for selected parameters computed with respect to monthly averages for

6 the $1993-2002$ period at BATS site. CA corresponds to cyclone - anticyclone interactions.

7 A, MWE and C correspond to anticyclones, mode water eddies and cyclones, respectively

8 (c, center; e, edge). NCPe is indirect estimates of net community production; PP, primary

9 production; $\mathrm{BR}$, bacterial respiration (computed assuming $\mathrm{BGE}=0.13$ ); $\mathrm{O}_{2}$ anomaly, $\mathrm{O}_{2}$ in

10 situ $-\mathrm{O}_{2}$ saturation in the upper $200 \mathrm{~m}$; POC (DOC), particulate (dissolved) organic carbon.

11 Prochlorococcus, Synechococcus, dinoflagellates and diatoms represent the percent

12 chlorophyll-a contributed by these groups. Bacteria is bacterial biomass and Cflux vertical

13 carbon flux from sediment traps. Error bars represent standard errors. See table 2 for depth14 integration intervals. 


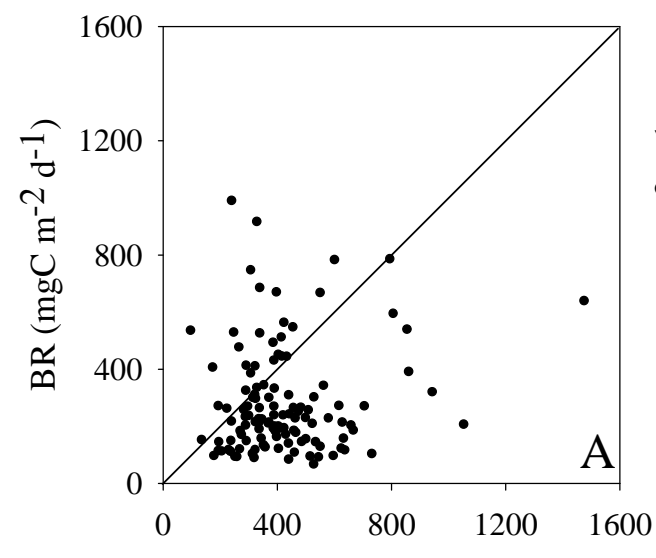

${ }^{14} \mathrm{C}$ PP $\left(\mathrm{mgC} \mathrm{m} \mathrm{m}^{-2} \mathrm{~d}^{-1}\right)$
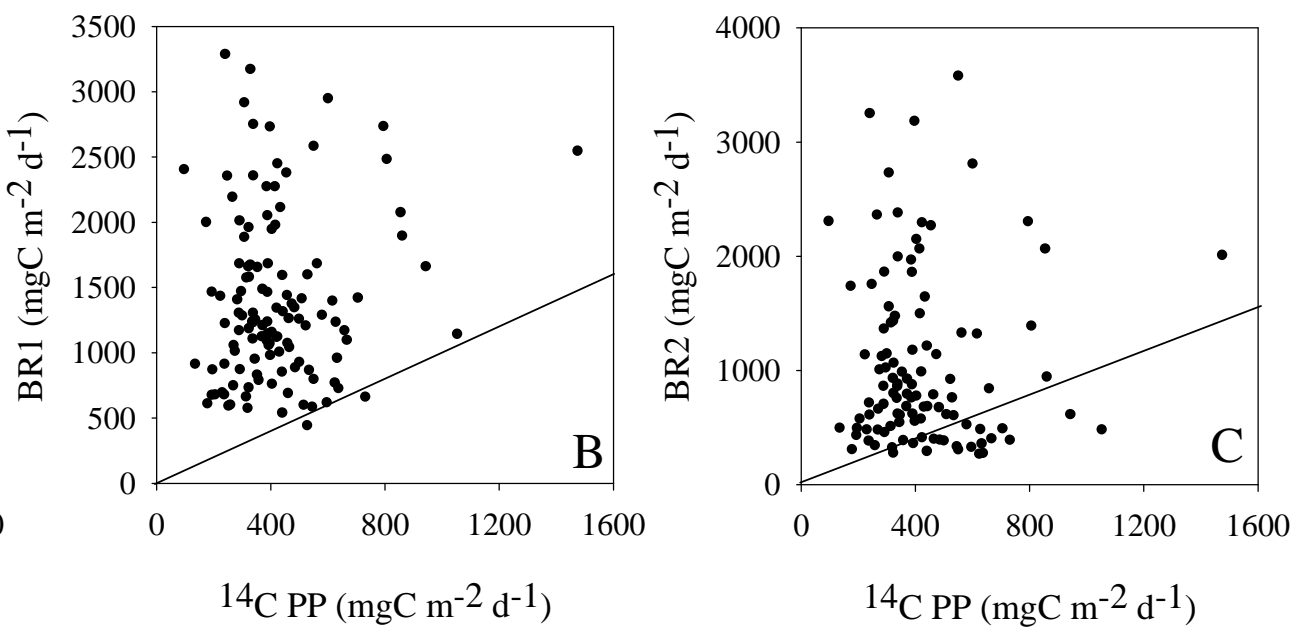

Figure 1 

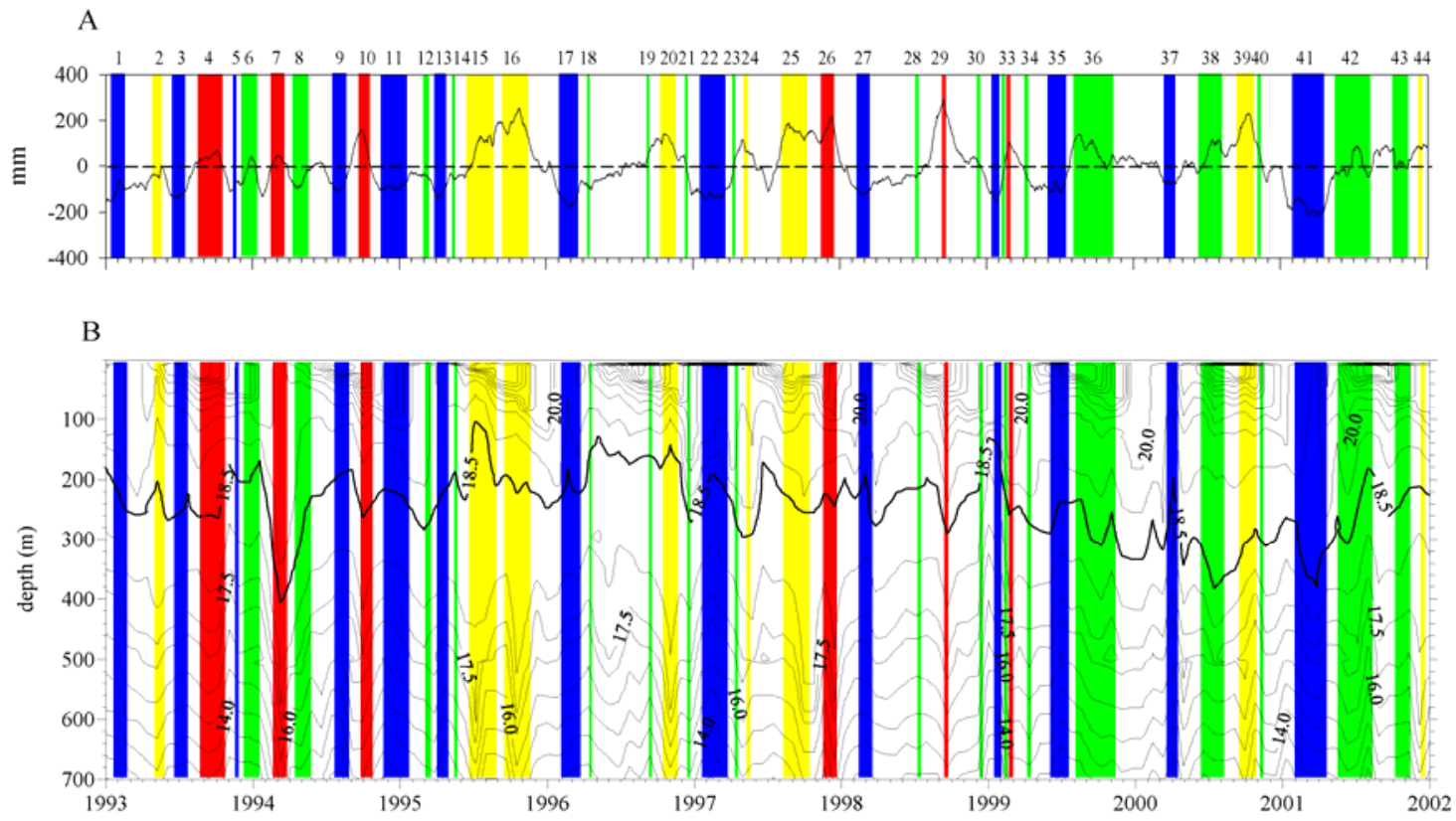

Figure 2 


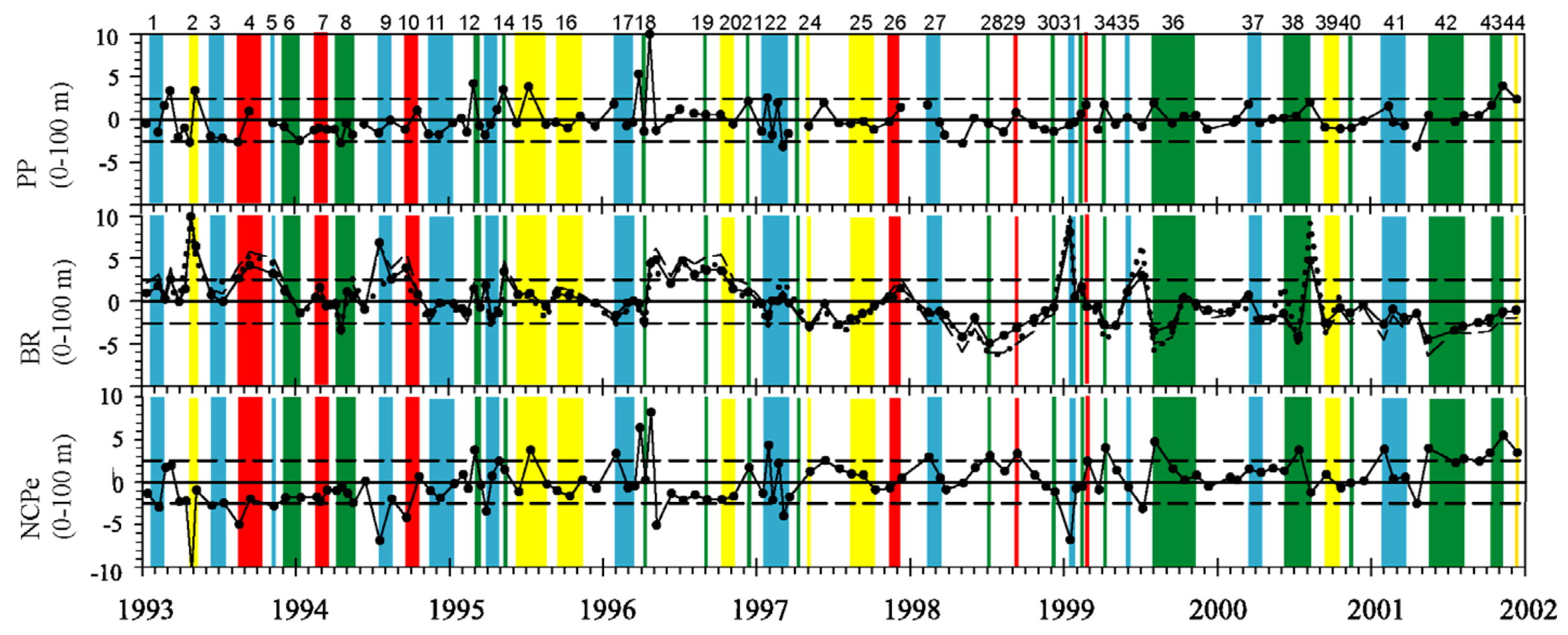

Figure 3 

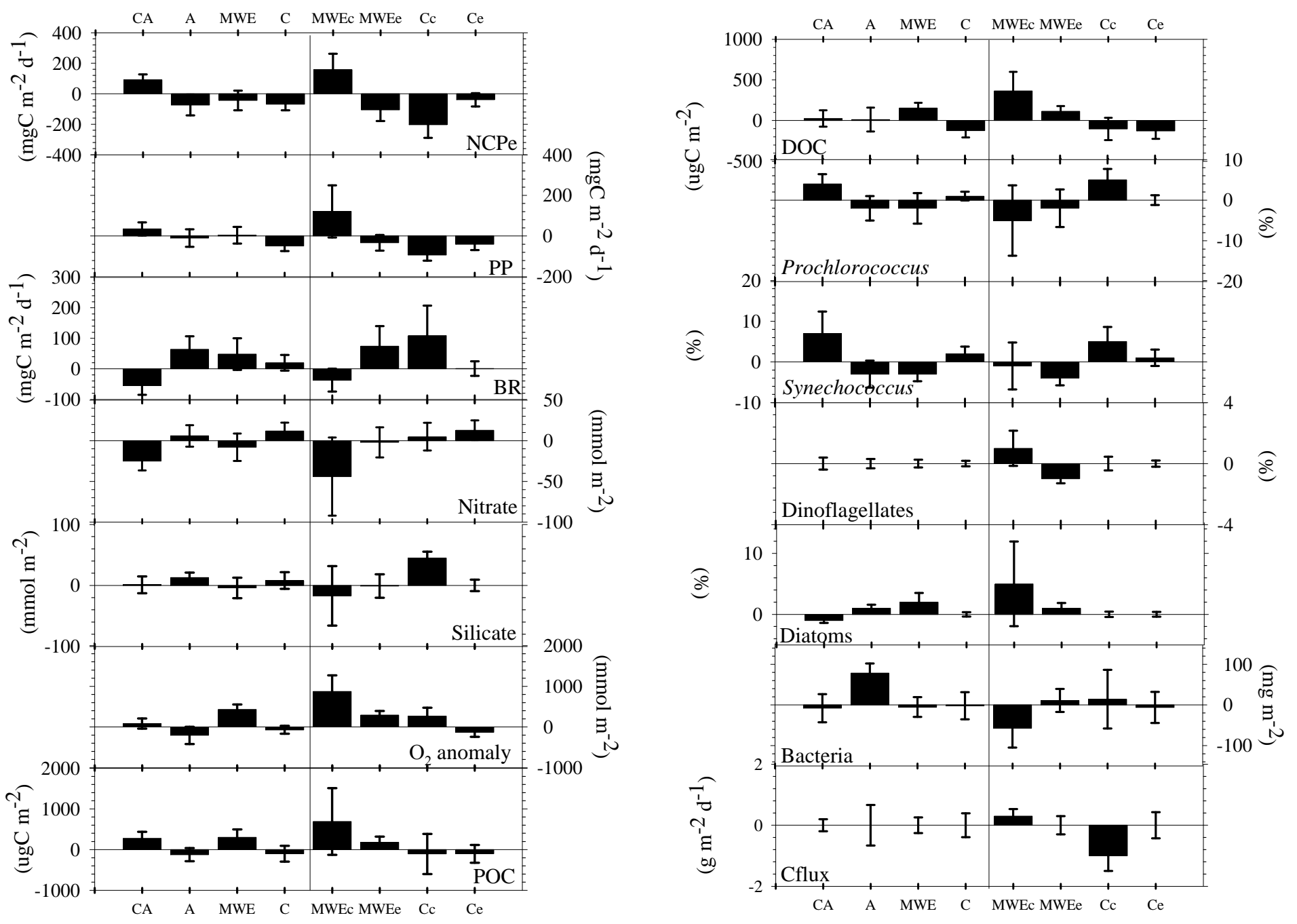

Figure 4 